(c) McDuff, Nona, Hughes, Annie, Tatam, John, Morrow, Elizabeth and Ross, Fiona (2020) The definitive, peer reviewed and edited version of this article is published in Widening Participation and Lifelong Learning, 22(2), pp. 83-121., DOI:

https://doi.org/10.5456/WPLL.22.2.83 


\title{
Improving equality of opportunity in higher education through the adoption of an Inclusive Curriculum Framework
}

\author{
Nona McDuff OBE, Solent University \\ Email: nona.mcduff@solent.ac.uk \\ Dr Annie Hughes, Kingston University \\ Email: a.hughes@kingston.ac.uk \\ John Tatam
}

Email: j.tatam@kingston.ac.uk

Dr Elizabeth Morrow

Email: elizabethmmorrow@hotmail.co.uk

Prof Fiona Ross CBE, Kingston University

Email: f.m.ross@sgul.kingston.ac.uk

\begin{abstract}
Within higher education, inclusion of students from diverse nations, socio-economic, ethnic and cultural backgrounds is vital for social mobility and economic development. Despite some international successes in widening participation, inequalities in student experiences and differentials in degree attainment for traditionally underrepresented groups, remain a major challenge. Institutional approaches to inclusion that value diversity as an inherent source of learning are underdeveloped. This paper adds theoretical insights and evidence to the debate on inclusive curricula by showing the benefits of institutional change through a strategic approach and innovation in practice (case studies). We argue that the Inclusive Curriculum Framework (ICF) underpinned by core principles of inclusion, can enhance equality of opportunity all the way through the student journey. The paper innovatively and rigorously bridges theory and practice in relation to inclusivity in learning and teaching and student success. It describes early and positive impact at Kingston University, adoption and spread in other institutions in England and potential international relevance.
\end{abstract}

Key words student diversity, BME attainment gap, widening participation, equality of opportunity, inclusive curriculum, social mobility 


\section{Introduction}

Within higher education (HE), inclusion of students from diverse nations, socio-economic, ethnic and cultural backgrounds is recognised as being vital, not only for social mobility (Universities United Kingdom (UUK), 2016) but also for economic gain and development (Toni, 2011; Thornton et al. 2010; Zepke and Leach, 2007; Nunan et. al. 2000). University graduates are on average financially better off (Department of Business Innovation and Skills, 2013; Higher Education Academy (HEA), 2014) experience better health, and are less likely to be unemployed (UUK, 2016; United States Department Education , 2016). Although internationally, agendas to widen participation (WP) have increased student numbers and increased the proportion of underrepresented groups (Archer, 2007; Burke 2012; United States Department Education, 2016; European Commission, 2019), inequalities in student experiences and differentials in degree attainment for traditionally underrepresented groups remain a major challenge (Office for Students (OfS), 2019; Equality Challenge Unit (ECU), 2015; Higher Education Funding Council (HEFCE), 2015).

Accounts from 'non-traditional' (first-generation university students, students from low-income households, students from minority ethnic/racial backgrounds, mature students age 21 or over, and/or students with a declared disability) students entering HE suggest they may feel out of place, marginalised, 'othered' and undervalued (Reay et al. 2010; Meuleman et al., 2015; Soria and Bultmann, 2014). In the UK, HE institutions are required to develop access and participation plans (OfS, 2019) which give consideration to factors which might affect students' sense of belonging within academic cultures and engagement in teaching and learning (ECU, 2015, HEFCE, 2015, Singh, 2011, Berry and Loke, 2011). Although interest in establishing best practices is growing in the UK and internationally, institutional approaches that go further and value student diversity as an inherent source of learning are underdeveloped (McDuff et al., 2019).

The aim of this paper is to explain how an Inclusive Curriculum Framework (ICF) was introduced at Kingston University in England to enhance equality of opportunity all the way through the student journey by integrating multiple narratives of inclusion into a holistic framework. The ICF can be used as a flexible tool for practice that is underpinned by core principles of inclusion. We draw on theories, policies and evidence around inclusion, explain the context behind the development of the ICF particularly in relation to the Black and Minority Ethnic (BME) attainment gap and identify factors that have supported the adoption of the ICF at Kingston University and the next steps to be taken. Our thinking has been informed by equality of opportunity as described by Lazenby (2016) and before that Western (1985). It provides a useful lens to explore the issues of inclusion, as it encourages systems 
thinking at an institutional level and emphasises the intersectionality of inclusion in terms of demographic and non-demographic factors.

\section{Background}

\section{Inclusive curricula}

Inclusion is widely espoused as an institutional value and/or focus for pedagogy and academic practice (Wray, 2013), but to our knowledge, there have been few attempts at practical application at the institutional level. For example, there are extensive bodies of evidence and theory on inclusive education (Nunan, et al., 2000) and inclusive learning and teaching in HE (Thomas and May, 2010), as well as a body of international literature (Bendermacher et al., 2019; Collins et al., 2018; McCarthy-Brown, 2014; Wray, 2013; Manley and De Graft-Johnson, 2013; Carey, 2012; Garvey, 2011).

An inclusive curriculum has been defined as 'improving the experience, skills and attainment of all students by ensuring that the principles of inclusivity are embedded within all aspects of the academic cycle' (HEA, 2019). Clearly each institution will have its own socio-political-economic context, values (Lazenby, 2016), structures and cultures (Madriaga, 2018; Runneymede, 2015; Douglas and Halas, 2013; Thornton et al., 2010), which begs the question what is the best way to respond to multiple equality challenges? (Swanger, 2016). In our view, institutions need to respond to the hyper-diversity in a systematic and systemic way. The potential advantages of an inclusive curriculum are that it clarifies institutional goals for inclusion (Lazenby, 2016), provides inspiration for transformational change (Wray, 2013; Thomas and Tight, 2011) and offers beneficial outcomes for students and society. By simplifying and 'sense making' complex and abstract perspectives of equality and inclusion into rubrics for best practice (May and Bridger, 2010), an inclusive curriculum can have practical utility in all discipline contexts. This paper moves beyond the theory to the practical questions of what works and provides some insights for others.

\section{Context of development for the ICF}

Development of the ICF at Kingston University was prompted by the needs of our increasingly diverse student population. BME students make up over half of the university's intake (Higher Education Statistical Agency ${ }^{1}$ (HESA), 2018/2019), which reflects improvements in the participation of domiciled BME students nationally from $14.95 \%$ in $2003 / 2004$ to $23.9 \%$ in $2017 / 18$ so that BME school leavers are now more likely to attend university than white school leavers (Advance HE 2019). However, in the shadow of these

\footnotetext{
${ }^{1}$ HESA, the Higher Education Statistics Agency, are the experts in UK higher education data, and the designated data body for England.
} 
successes, evidence was emerging about inequalities in the experiences and success of some student groups, at Kingston and across the sector (HEFCE, 2015).

BME students are more likely to: discontinue their studies (HEA, 2014; Stevenson, 2012), report the lowest levels of student satisfaction (HEFCE, 2015), attain lower grades (Richardson, 2015, 2012, 2008), and have the lowest rates for continuation to employment or further study (IFS, 2016; McDuff et al., 2018). In the UK white students are far more likely to receive a $1^{\text {st }}$ or 2:1 degree than BME students (Ross et al., 2018; Berry and Loke, 2011; Broeke and Nicholls, 2007). In 2017, 21\% more of the UK domiciled white student cohort received a 1st or 2:1 than the UK domiciled BME student cohort (ECU, 2018). Differentials cannot be explained by differences in entry qualifications or subjects of study (HEFCE 2015; McDuff et al., 2018). Nor are they due to deficits in student ability (Richardson, 2015, 2008;) a view which only serves to perpetrate racial stereotypes (Karanxha et al., 2014; Bhopal, 2017). The reasons are multifaceted and complex and thus require strategic and systemic changes (Berry and Loke, 2011) rather than piecemeal interventions.

Alongside concerns about ethnicity, research by HEFCE (2015) also found that there was an unexplained degree attainment gap of 3 percentage points between disabled and non-disabled graduates. The changes to the administration of the Disabled Students' Allowance (DSA-QG, 2016) also required the HE sector to think holistically about its offer and reduce the need for additional specialist support by embedding inclusivity in the design, delivery and assessment of the curriculum. Other research on students from lower-socio economic backgrounds found they 'have lower continuation, degree attainment and employment rates compared to their more advantaged peers' (UUK. 2016, p16). Given the significance of parental background in determining graduate outcomes (Britton, et al. 2016) it is vital that HE institutions provide an inclusive environment within and beyond the classroom.

\section{Vision for the ICF}

Development of the ICF began in 2012 led by the Director of Equality, Diversity and Inclusionallow who was joined by a small team of interested academic and research staff in 2014. Our experiences as teachers, researchers and leaders told us that an inclusive curriculum could benefit students from all backgrounds, and the university, by improving student engagement with learning, belonging and attainment (ECU, 2015, HEFCE, 2015, Singh, 2011, Berry and Loke, 2011). We were aware that inequalities are attributable to the interaction of many factors at multiple levels (Mountford-Zimdars, et al., 2015) thus, an inclusive curriculum would need to take into consideration factors associated with exclusion in the wider $\mathrm{HE}$ context, within the 
institution, and relational factors at the level of practice (e.g. student expectations about learning interactions).

Our vision was for an inclusive curriculum to ensure equality of opportunity all the way through the student journey, building on successes in WP and connecting with different dimensions of inclusion (disability, socioeconomic disadvantage, gender, race and so on) and equality goals (e.g. student experience, attainment gaps, social mobility). Moreover, an inclusive curriculum would value and utilise student diversity as a source of learning and enhance teaching through sharing diverse perspectives and experiences through the curricula (Wray, 2013).

Although at Kingston, and elsewhere within HE, there was evidence of isolated initiatives promoting inclusivity (Mountford-Zimdars, et al., 2015) these were not co-ordinated or connected to an institutional vision (Carey, 2012: 752). Development of the ICF offered a strategy to ensure 'equity considerations being embedded within all functions of the institution and treated as an ongoing process of quality enhancement' (May and Bridger, 2010, p.6). Our work on inclusive cultural change (McDuff, et al. 2015), suggested that to be successful, an inclusive curriculum should be designed and developed with staff and students to be a concise, relevant and practical framework that staff at all levels could easily apply to their own practice. Exploratory focus groups with BME, first generation and disabled students highlighted that they 'did higher education differently' giving credence to the idea of a holistic 'framework' that could be adapted to suit different contexts. The next step was to draw on evidence and theory to develop core principles of inclusion informing the ICF.

\section{Core principles of the ICF}

Drawing on inclusion policy, theory and evidence there are three core principles of the ICF:

Principle 1: Create an accessible curriculum

Principle 2: Ensure that students see themselves reflected in the curriculum

Principle 3: Equip students with the skills to positively contribute to and work in a global and diverse environment

These three principles are described below and depicted in Figure 1. The principles can be applied to every level of the curriculum from teaching session, module, programme, to the whole university, and for every phase of curriculum development; from the concept, to the content design and delivery, assessment, feedback, and review.

Figure 1 The Inclusive Curriculum Framework (all levels) 

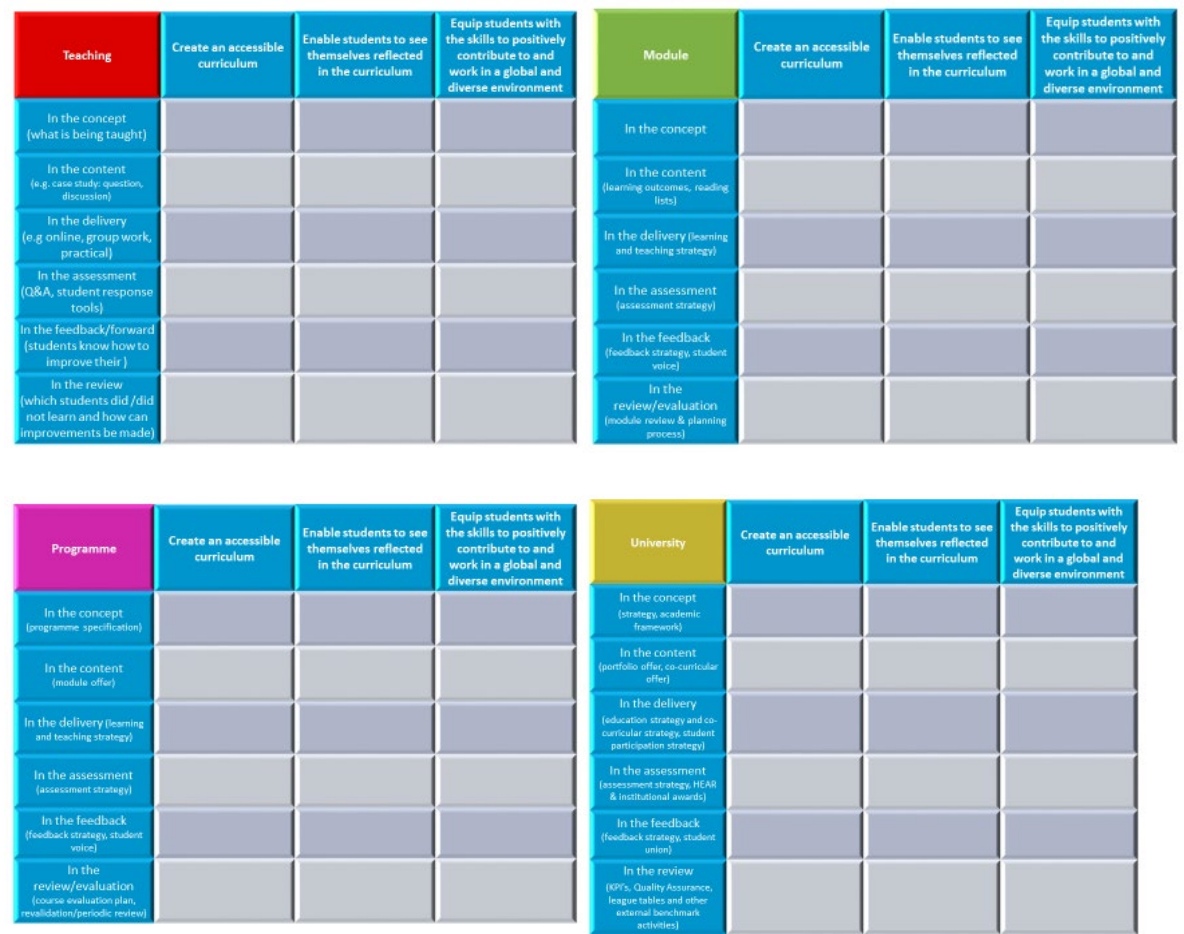

\section{Principle 1: Create an accessible curriculum}

Creating an accessible curriculum starts with understanding the legal (The Equality Act, 2010) and regulatory requirements for accessibility (e.g. Office for Students ${ }^{2}$ (OfS) and Teaching Excellence Framework). Institutions have a duty to make reasonable physical adjustment, such as improving access to buildings or learning materials (Disabled Students' Sector Leadership Group, 2017; May and Felsinger, 2010). In terms of methods of delivery, educational technologies and e-learning can help to improve access by supporting flexible part-time study and distance learning (Thomas and May, 2010; Reay et al., 2002) and modularised learning, which may suit mature students, students with caring responsibilities, work or other commitments (Reay et al., 2002; Seale et al., 2010). Balance is needed as e-learning doesn't suit all students and it can result in feelings of isolation and alienation, frustration or dissatisfaction and withdrawal (Thomas and May, 2010). Educators need to use accessible language and literacies (French, 2013; McKay \& Devlin, 2014) and take into account preferred ways of communicating and cultural learning styles (Haigh, 2002). As well as physical access, an accessible curriculum also makes concepts of 'higher' education accessible. In an inclusive curriculum, students' learning should include understanding of academic concepts, such as academic intelligence (Cameron, 2019), expertise, merit, reputation and gravitas, which can serve to divide or position them within an academic hierarchy (Cameron, 2017; Northedge, 2003).

${ }^{2}$ Office for Students is the regulatory body for the English higher education sector. 


\section{Principle 2: Ensure that students see themselves reflected in the curriculum}

This principle ensures that students are co-creators and they are not alienated or disadvantaged by a curriculum that is not relevant to them or excludes their culture, experience, values etc. An inclusive curriculum strengthens a student's sense of belonging through multiple aspects of the curriculum ranging from reading lists, case studies, choice of assessment topics as well as module and programme choices. It emphasises students' personal learning, objectives and ambitions (Rois et al., 2010), feedback, and views about learning (McDuff, Hughes and Sharma, 2019). At a more profound level, issues of cultural access relate to whether students' cultural backgrounds are acknowledged (e.g. in inclusive course values) and accommodated in the curriculum (May and Bridger, 2010; Song-Turner and Willis, 2011; Hammond et al., 2017). Staff need to be conscious of the 'grand narratives' (Savas, 2014; Tange and Kastberg, 2013; Maila, 2010; Hill, 2000; Hooks, 1994; Harding, 1986; Kelly, 1985) and patterns of privileged knowledge (e.g. Eurocentric, colonial and westernised) that are carried into the design of curricula (Mbembe, 2016), to the advantage of some groups of students while preventing others from fully engaging with curricula (Krause and Armitage, 2014; Gundara and Sharma, 2010; Reay, Ball \& David, 2002;).

Raising students' awareness of the partial and subjective nature of disciplinary knowledge (Marquis, et. al. 2016, McCarthy-Brown, 2014; Manley and De Graft-Johnson, 2013; Carey, 2012, Savvidou, 2011) means they are more able to critique what is accepted as important and legitimate knowledge (McCarthy-Brown, 2014). Co-produced approaches can involve students and other stakeholders (Hughes et. al., 2019; McCulloch, 2009) directly and actively in improving the relevance of curriculum design and course content (Tange and Kastberg, 2013; Bovill, 2009; Hockings, 2010). Students need to see 'people like them' in their everyday HE experiences (ECU, 2015; HEFCE, 2015; Douglas and Halas, 2013) as mentors, role models and authority figures (Rois et al., 2010) but also represented within case studies, as consumers, citizens, clients, and service users. Linked to this issue is the lack of women, BME staff, and other underrepresented groups in senior academic or management roles (HESA, 2017/18), which negatively affects students' experiences of HE (Bowl, 2005) and diversity of perspectives in institutional decision making (Blackmore et. al, 2006; Umbach, 2006). An inclusive curriculum suggests that students should be involved in decisions about curricula, quality assurance and assessment (McDuff, Hughes and Sharma, 2019).

"At the heart of the ICF is Kingston's understanding of what diversity actually means, and what empowering the students actually looks like. Perhaps the most important for us has been seeing the students foreground their own knowledge and experience in assessments, and this necessitated more than just incremental adjustments to assignments. The ICF has allowed 
us to make fundamental paradigm shifts rather than tokenistic and piecemeal adaptations to the programme." Course Leader, Kingston.

Principle 3: Equip students with the skills to positively contribute to and work in a global and diverse environment

An inclusive curriculum considers student diversity as an inherent educational value (Brinks, 2009). Inclusive strategies and learning approaches enable engagement and shared learning (McDuff, Hughes and Sharma, 2019), build student confidence and competence to engage, and set an expectation that they will engage in the workplace and society (Barnett and Coate, 2005). Students who interact with people from backgrounds that are different from theirs develop diversity competencies and are better able to collaborate with others from a variety of cultures, backgrounds and positions (Svensson and Wihlbord, 2010; Lee et al. 2012; Tienda, 2012; Haigh, 2009). An inclusive curriculum should offer 'opportunities for mixing of students, their perspectives and experiences' (Lee et. al., 2012). Social interaction is an important but under explored factor in student inclusion and student outcomes (Mountford-Zimdars, et al. 2015) but it is important to overcome social clusters and social divisions between students (Karimi and Matous, 2018).Recognition and rewards for student contributions to learning (e.g. student-led case study topics) can encourage students to value their own contribution and the contribution of others, in, for example performance in the workplace or benefits to society (Haigh, 2009). Whether students relate to educators and have positive relationships with them influences student experiences of learning (Hockings et al, 2009b). An inclusive curriculum should enable educators to overcome social distance and to convey 'relational equality' (Winter, 2017) through empathy, unconditional positive regard, and congruence; seeing student diversity as a strength of teaching and learning (Bowl, 2005; Madriaga, 2018). Students who are competent to connect with, draw upon and contribute to networks, employers, colleagues and communities (UUK, 2016) achieve better student outcomes (MountfordZimdars, et al. 2015). Educators can encourage students to see their intercultural skills and diversity (McKinsey, 2018) as valuable to employers and communities (Selko, 2008).

\section{Applying the theory of the ICF to practice}

We considered it important for the ICF to allow for a range of activities from light touch changes that are within the control of the staff member to those which require validation or senior level approval.

Figure 2 uses the ICF template to exemplify the changes that were made to a module on a Geography undergraduate programme which enhanced inclusivity of the curriculum. (Hughes and McDuff, 2020).

Figure 2 Changes made to a module to reflect the principles and stage 

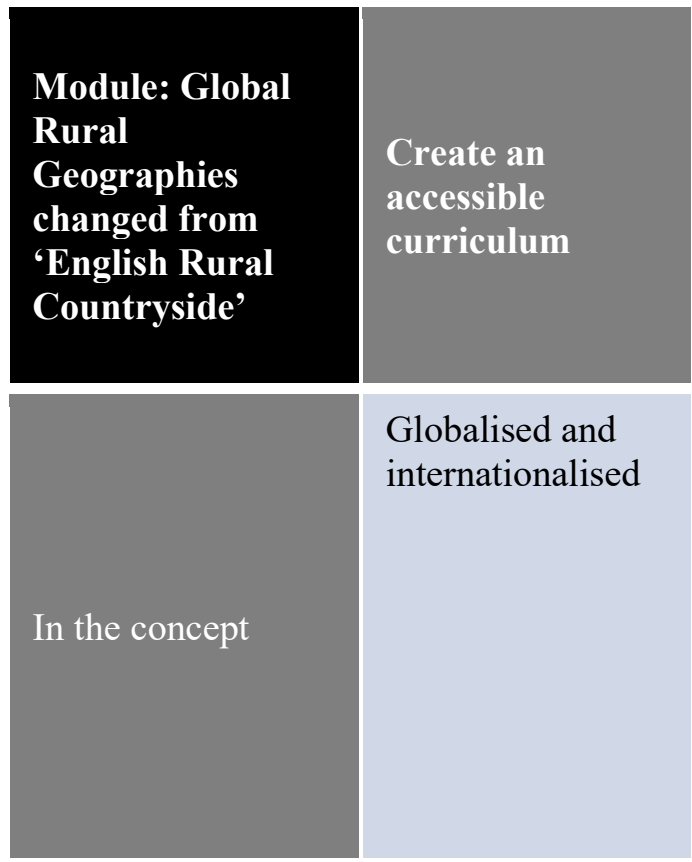

In the content

(learning

outcomes, reading lists)

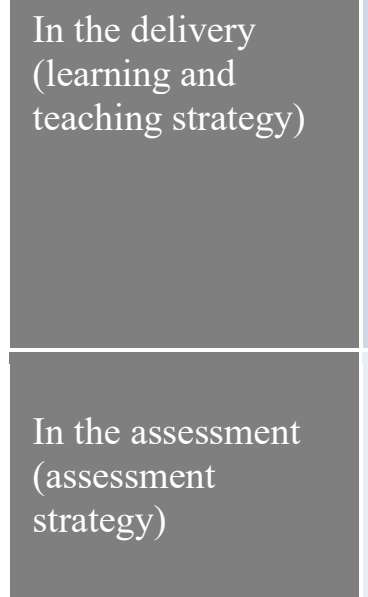

Enable

students to see

themselves

reflected in

the

curriculum

Globalised and internationalised

Case-studies were

taken from both the global north and the global south

\section{Engagement} strategy

Follow up on non-attendance, use of online and face to face learning opportunities

opportunities

Unseen exam was replaced by seen exam (since changed to

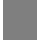

\section{Students from} diverse backgrounds have the opportunity to use their personal experiences and perspectives

\section{Reading list} included a diverse range of authors including perspectives from the Global South Non-academic perspectives were valued

\begin{tabular}{|c|c|}
\hline $\begin{array}{l}\text { Encourage } \\
\text { discussion } \\
\text { from personal } \\
\text { experience } \\
\text { Using names to } \\
\text { encourage } \\
\text { discussion and } \\
\text { viewpoints }\end{array}$ & $\begin{array}{l}\text { Seminars } \\
\text { classes - } \\
\text { discussion } \\
\text { based to } \\
\text { develop } \\
\text { individual skills } \\
\text { and } \\
\text { understanding } \\
\text { of the } \\
\text { contribution } \\
\text { each student } \\
\text { brings }\end{array}$ \\
\hline $\begin{array}{l}\text { Formative } \\
\text { assessment - } \\
\text { debate style } \\
\text { with students } \\
\text { selecting the }\end{array}$ & $\begin{array}{l}\text { Oral } \\
\text { presentations } \\
\text { part of the } \\
\text { assessment (in }\end{array}$ \\
\hline
\end{tabular}

Equip students with the skills

to positively contribute to and work in a global and

diverse environment

Critical thinking and global awareness, appreciation of different experiences

Understanding of globalisation and interlinkages

Equip students
with the skills
to positively
contribute to
and work in a
global and
diverse
environment
Critical
thinking and
global
awareness,
appreciation of
different
experiences

Understanding
of globalisation
and
interlinkages




\begin{tabular}{|l|l|l|l|}
\hline $\begin{array}{l}\text { service learning } \\
\text { piece) }\end{array}$ & $\begin{array}{l}\text { position that } \\
\text { they wish to } \\
\text { defend }\end{array}$ & $\begin{array}{l}\text { addition to } \\
\text { written skills) }\end{array}$ \\
\hline $\begin{array}{l}\text { Detailed feedback } \\
\text { - sectionalised by } \\
\text { indicative } \\
\text { marking criteria } \\
\text { Deadlines and } \\
\text { assessment set at } \\
\text { start of academic } \\
\text { year }\end{array}$ & $\begin{array}{l}\text { Feedback was } \\
\text { individualised } \\
\text { and oral and } \\
\text { written - oral } \\
\text { feedback was } \\
\text { in-class }\end{array}$ & $\begin{array}{l}\text { Ensured } \text { knew } \\
\text { all names }\end{array}$ & $\begin{array}{l}\text { Students } \\
\text { encouraged to } \\
\text { reflect on } \\
\text { feedback } \\
\text { comments and } \\
\text { mark - exercise } \\
\text { of self- } \\
\text { reflection and } \\
\text { discussion }\end{array}$ \\
\hline $\begin{array}{l}\text { In the } \\
\text { review/evaluation } \\
\text { (module evaluation } \\
\text { and planning } \\
\text { process) }\end{array}$ & $\begin{array}{l}\text { Module review } \\
\text { evaluated } \\
\text { differential } \\
\text { attainment } \\
\text { students from } \\
\text { different } \\
\text { backgrounds }\end{array}$ & $\begin{array}{l}\text { Involve } \\
\text { students in the } \\
\text { review and } \\
\text { evaluation } \\
\text { - Qualitative } \\
\text { discussion }\end{array}$ & $\begin{array}{l}\text { Reflective } \\
\text { practice-to } \\
\text { develop } \\
\text { employability } \\
\text { and leadership } \\
\text { skills; develop } \\
\text { opportunities to } \\
\text { value } \\
\text { contribution } \\
\text { diversity brings }\end{array}$ \\
\hline
\end{tabular}

Notwithstanding the importance of individual commitment to the principles of the ICF, we recognised that notable improvements to the student experience were dependent upon the cohesion of the course/module team. In order to provide practical guidance and encourage staff to think and behave as a course team we created a checklist to explain the ICF and to prompt action which is provided in Figure 3. These were also used to promote the ICF with academics involved in the Quality Assurance and validation processes.

Figure 3 ICF - Prompts for course teams and module leaders

\begin{tabular}{|ll|l|l|}
\hline \multirow{4}{*}{ Stages } & $\begin{array}{l}\text { Principle 1: } \\
\text { Create an }\end{array}$ & $\begin{array}{l}\text { Principle 2: } \\
\text { Enable students to } \\
\text { see themselves } \\
\text { reflected in the } \\
\text { curriculum }\end{array}$ & $\begin{array}{l}\text { Principle 3: } \\
\text { Equip students } \\
\text { to work in a } \\
\text { global and } \\
\text { diverse world }\end{array}$ \\
\hline Concept & $\begin{array}{l}\text { Have you } \\
\text { created a clear } \\
\text { statement related } \\
\text { to inclusive } \\
\text { course values }\end{array}$ & $\begin{array}{l}\text { - How have you } \\
\text { challenged } \\
\text { normative } \\
\text { disciplinary } \\
\text { attitudes to } \\
\text { ensure that the }\end{array}$ & $\begin{array}{l}\bullet \text { How will the } \\
\text { course aim to } \\
\text { develop } \\
\text { university } \\
\text { graduate } \\
\text { attributes }\end{array}$ \\
& & &
\end{tabular}




\begin{tabular}{|c|c|c|c|}
\hline & $\begin{array}{l}\text { within student } \\
\text { handbook? } \\
\text { - Have you } \\
\text { addressed the } \\
\text { 'hidden } \\
\text { curriculum' if } \\
\text { acknowledged in } \\
\text { the discipline } \\
\text { area? }\end{array}$ & $\begin{array}{l}\text { course is } \\
\text { meaningful and } \\
\text { relevant to a } \\
\text { diverse student } \\
\text { body? } \\
\text { - Have you } \\
\text { involved students } \\
\text { in the creation of } \\
\text { the course? }\end{array}$ & $\begin{array}{l}\text { around global } \\
\text { awareness and } \\
\text { diversity? }\end{array}$ \\
\hline Content & $\begin{array}{l}\text { - Have you } \\
\text { checked all the } \\
\text { content is } \\
\text { accessible to } \\
\text { different groups } \\
\text { of students and } \\
\text { materials adhere } \\
\text { to best practice } \\
\text { for disabled } \\
\text { students and } \\
\text { students with a } \\
\text { learning } \\
\text { difference? } \\
\text { - Are you using } \\
\text { inclusive } \\
\text { language, } \\
\text { avoiding } \\
\text { colloquial } \\
\text { language and } \\
\text { providing a } \\
\text { glossary of new } \\
\text { and complex } \\
\text { terms? }\end{array}$ & $\begin{array}{l}\text { - Have you } \\
\text { ensured that the } \\
\text { case-studies and } \\
\text { reading lists } \\
\text { reflect the } \\
\text { diversity in the } \\
\text { learning } \\
\text { community? } \\
\text { - Have you } \\
\text { thought about } \\
\text { how best to allow } \\
\text { students to bring } \\
\text { their own } \\
\text { perspectives into } \\
\text { the learning } \\
\text { arena ensuring } \\
\text { equality of } \\
\text { engagement? }\end{array}$ & $\begin{array}{l}\text { - Does the } \\
\text { content extend } \\
\text { understanding } \\
\text { of diversity } \\
\text { and allow } \\
\text { students to } \\
\text { recognise } \\
\text { their own } \\
\text { potential to } \\
\text { make a } \\
\text { difference in a } \\
\text { rapidly } \\
\text { changing } \\
\text { international } \\
\text { context? }\end{array}$ \\
\hline $\begin{array}{l}\text { Learning } \\
\text { and } \\
\text { teaching }\end{array}$ & $\begin{array}{l}\text { - Have you } \\
\text { thought about } \\
\text { how the delivery } \\
\text { engages } \\
\text { different } \\
\text { learning styles? } \\
\text { - Will the course } \\
\text { be delivered in } \\
\text { an accessible } \\
\text { mode and are } \\
\text { there alternative } \\
\text { options provided } \\
\text { for students who }\end{array}$ & $\begin{array}{l}\text { - How does the } \\
\text { L\&T strategy } \\
\text { ensure that the } \\
\text { classroom } \\
\text { environment is } \\
\text { welcoming and } \\
\text { inclusive and } \\
\text { encourages } \\
\text { participation } \\
\text { from under- } \\
\text { represented } \\
\text { groups? }\end{array}$ & $\begin{array}{l}\text { - Are there } \\
\text { structured } \\
\text { opportunities } \\
\text { for cross- } \\
\text { cultural } \\
\text { interaction to } \\
\text { help students } \\
\text { recognise the } \\
\text { value of } \\
\text { working with } \\
\text { people from } \\
\text { diverse } \\
\text { backgrounds? }\end{array}$ \\
\hline
\end{tabular}




\begin{tabular}{|c|c|c|c|}
\hline & $\begin{array}{l}\text { cannot access } \\
\text { specific delivery } \\
\text { mechanisms? }\end{array}$ & $\begin{array}{l}\text { Have the course } \\
\text { team engaged in } \\
\text { unconscious bias } \\
\text { and equalities } \\
\text { training? }\end{array}$ & $\begin{array}{l}\text { - Are students } \\
\text { exposed to a } \\
\text { range of } \\
\text { culturally } \\
\text { challenging } \\
\text { views, } \\
\text { opinions and } \\
\text { contexts? } \\
\end{array}$ \\
\hline Assessment & $\begin{array}{l}\text { - Are timelines } \\
\text { (formative, } \\
\text { summative and } \\
\text { feedback) } \\
\text { advised at the } \\
\text { start of the } \\
\text { course? } \\
\text { - Are a diverse } \\
\text { range of } \\
\text { assessments } \\
\text { styles (including } \\
\text { choice) used to } \\
\text { reduce the need } \\
\text { for reasonable } \\
\text { adjustments and } \\
\text { ensure that the } \\
\text { assessment } \\
\text { medium reflects } \\
\text { their own } \\
\text { strengths and } \\
\text { educational } \\
\text { backgrounds? }\end{array}$ & $\begin{array}{l}\text { - Do the case- } \\
\text { studies/vignettes } \\
\text { used in the } \\
\text { assessment } \\
\text { reflect the } \\
\text { diversity in our } \\
\text { student body? } \\
\text { - Are there } \\
\text { assessments } \\
\text { where students } \\
\text { can draw upon } \\
\text { their own } \\
\text { background? e.g. } \\
\text { 'open' } \\
\text { assessment } \\
\text { where students } \\
\text { can apply a } \\
\text { particular } \\
\text { principle to } \\
\text { familiar } \\
\text { contexts? }\end{array}$ & $\begin{array}{l}\text { - How will the } \\
\text { assessment } \\
\text { strategy } \\
\text { ensure that } \\
\text { students are } \\
\text { involved in } \\
\text { real-world } \\
\text { tasks that } \\
\text { demonstrate } \\
\text { meaningful } \\
\text { application of } \\
\text { essential } \\
\text { knowledge } \\
\text { and skills? } \\
\text { - How does } \\
\text { assessment } \\
\text { develop the } \\
\text { practical skills } \\
\text { (including soft } \\
\text { or work-ready } \\
\text { skills) in } \\
\text { students? }\end{array}$ \\
\hline Feedback & $\begin{array}{l}\text { - Are students } \\
\text { offered exercises } \\
\text { which develop } \\
\text { their assessment } \\
\text { literacies and } \\
\text { effective ways to } \\
\text { use their } \\
\text { feedback? } \\
\text { - Are there } \\
\text { processes in } \\
\text { place to monitor } \\
\text { which cohorts of } \\
\text { students are } \\
\text { accessing their } \\
\text { feedback? }\end{array}$ & $\begin{array}{l}\text { - How is the issue } \\
\text { of 'social } \\
\text { distance' being } \\
\text { addressed in } \\
\text { feedback } \\
\text { strategies? i.e. } \\
\text { some students } \\
\text { feel less } \\
\text { confident or able } \\
\text { to approach } \\
\text { academic staff } \\
\text { than others. }\end{array}$ & $\begin{array}{l}\text { - How are } \\
\text { students } \\
\text { encouraged to } \\
\text { actively adopt } \\
\text { a reflective } \\
\text { approach to } \\
\text { their learning } \\
\text { and facilitate } \\
\text { the } \\
\text { development } \\
\text { of their } \\
\text { feedforward } \\
\text { strategies? } \\
\text { - How are peer- } \\
\text { review }\end{array}$ \\
\hline
\end{tabular}




\begin{tabular}{|c|c|c|c|}
\hline & & & $\begin{array}{l}\text { practices } \\
\text { encouraged to } \\
\text { ensure that } \\
\text { students learn } \\
\text { to engage in } \\
\text { constructive } \\
\text { feedback } \\
\text { strategies with } \\
\text { each other? }\end{array}$ \\
\hline Review & $\begin{array}{l}\text { - How will } \\
\text { differential } \\
\text { attainment be } \\
\text { monitored? } \\
\text { - Are there } \\
\text { opportunities to } \\
\text { engage students } \\
\text { in devising or } \\
\text { re-visiting the } \\
\text { content and } \\
\text { learning and } \\
\text { teaching and } \\
\text { assessment } \\
\text { strategies? }\end{array}$ & $\begin{array}{l}\text { - How will the } \\
\text { course team } \\
\text { monitor how the } \\
\text { course is being } \\
\text { experienced by } \\
\text { diverse cohorts } \\
\text { of learners? } \\
\text { - How will the } \\
\text { course team } \\
\text { ensure that } \\
\text { students from a } \\
\text { diverse range of } \\
\text { backgrounds get } \\
\text { involved in the } \\
\text { review and } \\
\text { evaluation of the } \\
\text { course or } \\
\text { module? }\end{array}$ & $\begin{array}{l}\text { - How will the } \\
\text { course team } \\
\text { utilise alumni } \\
\text { to review the } \\
\text { ways in which } \\
\text { the } \\
\text { course/module } \\
\text { best prepared } \\
\text { them for the } \\
\text { global } \\
\text { workforce? }\end{array}$ \\
\hline
\end{tabular}

\section{Adoption of the ICF}

This section of the paper draws on our experiences of adopting the ICF at Kingston to identify factors that have been most important for supporting adoption, acknowledging that the adoption represents the early stages of the implementation process (Rogers, 1962). It is important to note that the catalyst for the ICF were the proposed changes to the Disabled Students' Allowance $^{3}$ and the adoption of the BME attainment gap Key Performance Indicator (KPI) at the University (described in Measuring impact) which was a cultural change programme. Implementation aimed to ensure that the ICF

\footnotetext{
${ }^{3}$ The changes to the Disabled Student's Allowance rebalance the distribution of responsibility for disabled students between HEls and the Government. These changes required universities to build greater inclusivity into the curriculum thereby reducing the need for Government funding at an individual level.
} 
was embedded into the whole organisation using a variety of approaches, illustrated by Figure 4 and outlined below.

\section{Figure 4: Adopting the Inclusive Curriculum Framework}

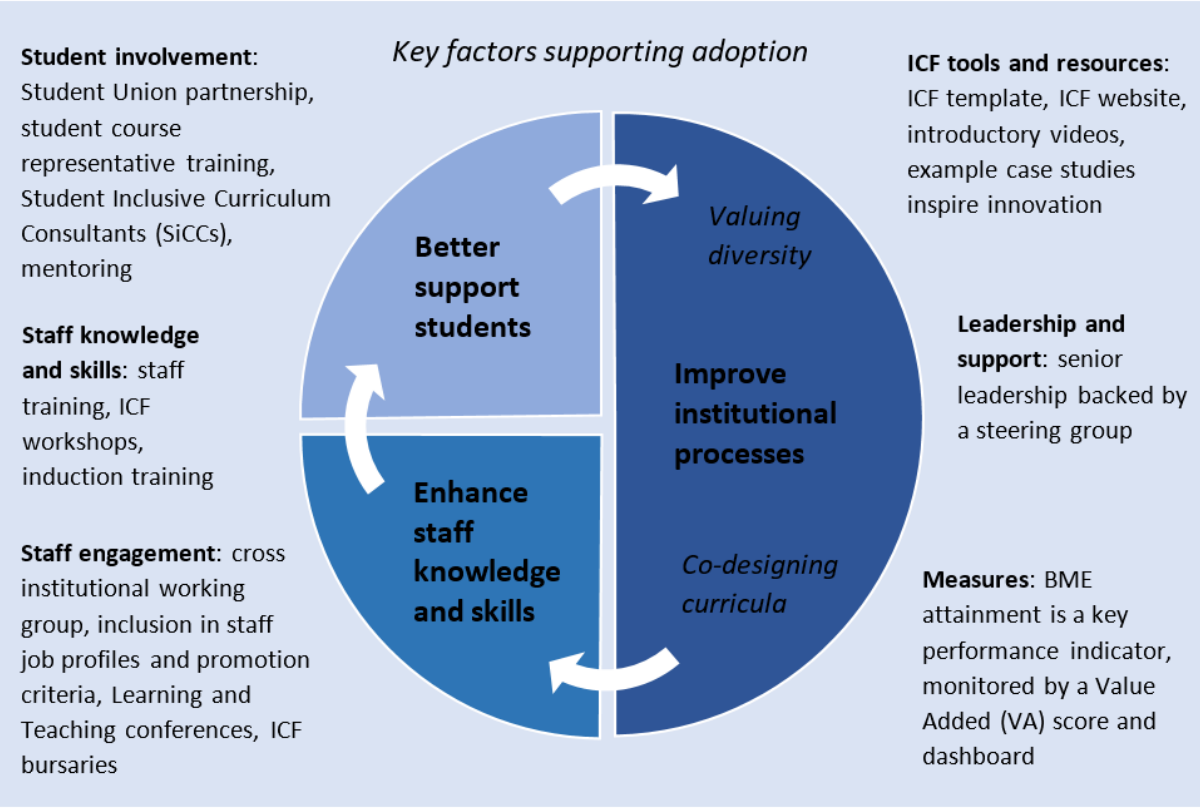

\section{Easy to use ICF tools and resources:}

Kingston's ICF web pages and a series of short animations explain the ICF (https://www.kingston.ac.uk/aboutkingstonuniversity/equality-diversityand-inclusion/our-inclusive-curriculum/inclusive-curriculum-framework/). The ICF is available as a workable tool (a template) that users can fill with information and ideas about possible intervention points where improvements could be made within their sphere of influence (from individual teaching sessions to across the whole university). Figure 3 provides the example of prompts that have been developed specifically for course teams and module leaders. The ICF template is a structured tool, but its value and effectiveness come from being used not only as a checklist, but as a means of exploration and discussion of inclusion issues. This developmental perspective has been engendered by leadership and support, described below.

\section{Leadership and support:}

Leadership of implementation of the ICF was provided by the Director of Student Achievement and the Head of Academic Staff Development. This has resulted in an integration of the ICF into university processes and practice, alignment with national and institutional standards initiatives (e.g. UK Professional Standards Framework, Quality Assurance Agency, and Teaching Excellence Framework) and connections with other universities that are interested in inclusive curricula. The Vice Chancellor, PVC Education, the Board and senior management endorse the ICF at a strategic 
level, and since 2015 have formally mainstreamed the ICF in the academic framework from concept to review and continue to champion the work and good practice. Support for co-creation projects (2017-current) is provided by a co-ordinator who manages the Student Inclusive Curriculum Consultant (SiCC) programme.

\section{Staff engagement:}

A cross-institutional working group (2016-current) of academics, professional services staff and student representatives, identify ways to improve staff knowledge of the ICF, support staff in their academic practices, collect and share good practice, and identify any barriers to staff engagement with the ICF. Staff are made aware of the central role that the ICF has in delivering the institution's commitment to inclusion. Staff performance on inclusive practice is written into academic role profiles and promotion criteria. A Special Interest Group for education research on Inclusion and Social Justice, Learning and Teaching conferences and inclusive curriculum bursaries encourage staff to share learning and innovation.

\section{Staff knowledge and skills:}

Staff on probation and new to teaching are required to take part in an introduction to learning and teaching programme in which ICF principles are embedded. All staff are invited to attend workshops on 'Unconscious Bias' and 'Equality Essentials'. The workshops are interdisciplinary to encourage reflection on different disciplinary and epistemological understandings of inclusion (Bendermacher et al., 2019). Interactive ICF workshops provide teaching staff with discretionary space to apply their own knowledge and wisdom to the ICF in practice.

"I attended EDI and ICF workshops and had been ambivalent about initiatives such as "decolonising the curriculum" as they seemed more relevant to the Humanities and Social Sciences and were mainly focused on content and people's contributions to the field. The aspect that resonated most with me was that these workshops recognised that much more was needed than just changing the content of courses. The fact that the framework gave equivalent emphasis to thinking about the concept, content, teaching style, assessment and review of programmes opened up a lot more possibilities and ideas of how the curriculum could be made more inclusive." Director of Undergraduate Studies.

Inevitably, as with all new concepts and change programmes, there was some resistance to the ICF. Given the reliance on epistemologies grounded in universal truth, we anticipated greater resistance in STEM rather than social sciences programmes, but this was not always the case. For example, a course leader in pharmacology used the ICF to change practice and has recently been shortlisted for a Guardian Excellence award (2020) in the course design, retention and student outcomes and a senior leader in STEM is writing a paper 
on the implementation and benefits of the ICF in their field. In contrast, adoption of the ICF has been slower in some social science disciplines, primarily due to deeply rooted views on academic standards and disciplinary norms, resulting, for example, in the de-legitimisation of knowledge from the global south.

\section{Student involvement:}

Representatives of the Student Union ${ }^{4}$ (SU) have been consistently involved throughout the development and implementation of the ICF. Since 2016 over 300 student course representatives have received ICF training. A further 80 paid Student Inclusive Curriculum Consultants (SiCCs) have been trained in inclusive curriculum design (drawing on Bovill, 2009, McCulloch, 2009, Hughes et al, 2019) and equality, diversity and inclusion more broadly to enable them to make a more informed contribution at the ICF's institutional level. Student training has now been scaled down to focus on senior course representatives who have more opportunities to contribute to the curricula. At present two Senior Curriculum Consultants (post-grad students) provide support to eight SiCCs. Examples of the work they have undertaken include: improving the accessibility and relevance of assessment, ensuring the Virtual Learning Environment course materials are student friendly, working with the marketing department to ensure diverse students can see themselves in the marketing material.

"Because the ICF is an institutional framework it supports students who are presenting ideas to improve the inclusivity of the curriculum. It makes it easier for us to work with academics and the training is also important in helping students to be confident in making recommendations." Senior Curriculum Consultant.

\section{Measuring impact:}

The ICF is one of the major strategies used to reduce the BME attainment gap which is a KPI adopted by the Board of Governors to make the university accountable for performance on inclusion. A Value-Added (VA) metric has been developed to monitor BME attainment (McDuff et al., 2018). The metric uses the actual degree outcomes of all UK graduates in the last five years by subject of study and entry qualification to create a statistically expected percentage of 1st/2:1 degrees for any given cohort (Ross et al., 2018). Where attainment is better than the expected, the VA score is proportionately above 1.0 , and conversely where the outcome is below expectation the score is below 1.0. A VA dashboard displays past and present scores by faculty, school and course. Meetings with course teams (over 120 to date) are held to ensure they fully understand their course VA score, and to facilitate

${ }^{4}$ At UK higher education institutions all students are members of the local student union. Unions carry out social activities; provide support on academic and welfare issues; and represent students both individually and collectively. 
sometimes quite challenging conversations about race, diversity and their role in improving outcomes of all students. Staff invariably want to know what to do to narrow the differentials in their courses and the ICF provides tools and resources to do this. The VA metric and the ICF work together to create action and change.

As can be seen from Figure 5, the VA score for BME students has increased from 0.72 to 0.99 during the period $2011 / 12$ to $2016 / 17$.

Figure 5 Value Added Score for White and BME graduates 2011/12 2016/17 (source: Kingston University)

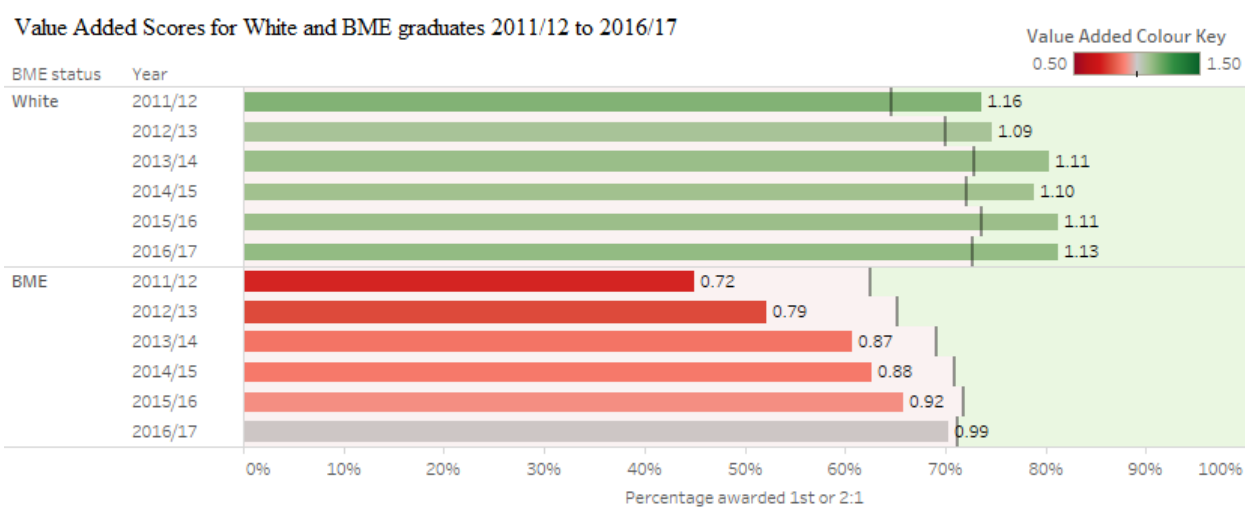

The BME attainment gap has reduced from 29 percentage points (pp) in 2011/12 (and as can be seen from Figure 6) and 20.4pp in 2013/14 to $11.1 \mathrm{pp}$ in $2017 / 18$. Whilst these changes cannot be directly attributable the ICF, it is important to note that the ICF has been the key institutional tool that has been used in creating discussions about what needs to change and how to go about making these changes at all levels.

Figure 6 Full time attainment gap analysed by ethnicity for Kingston University and All English HE providers (source: Office for Students) 


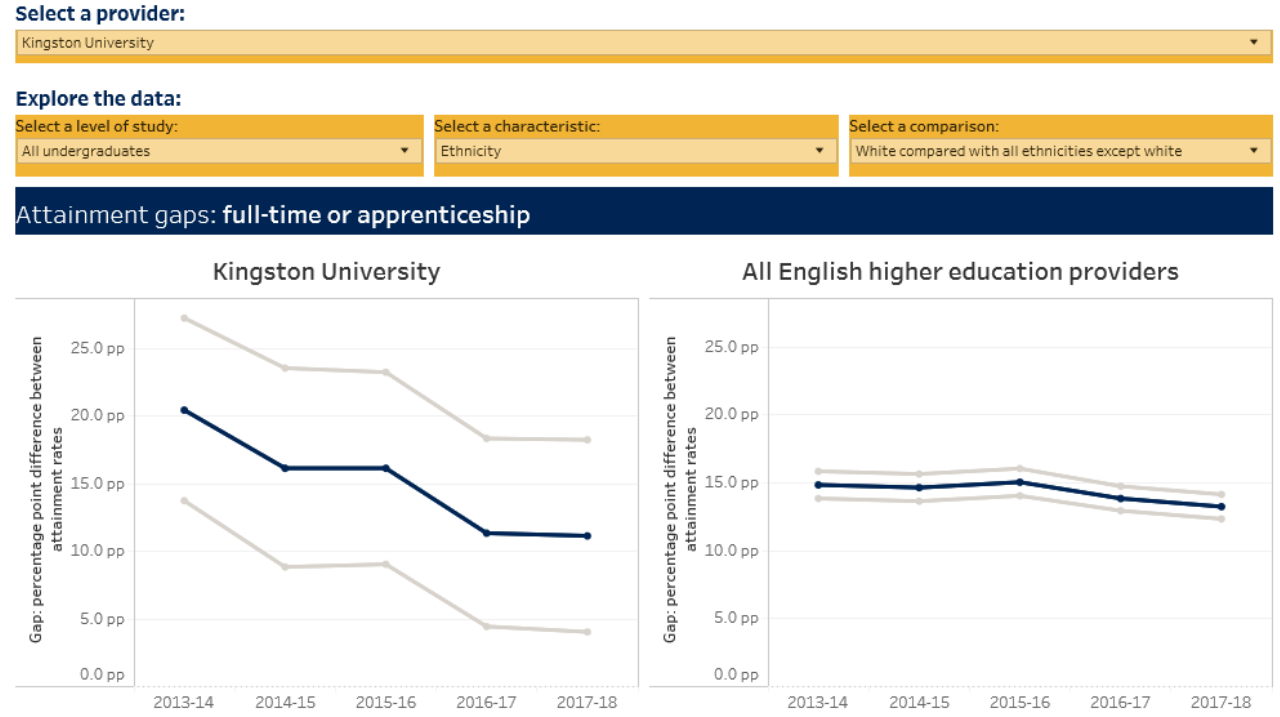

The number of reported changes to practice at institutional and course levels, and fewer exam resits, are other ways to measure impact.

The leaders of the ICF have used it to facilitate other changes at the institutional level such as Flexi-stay motel type accommodation for commuting students, marketing material, the increasing analysis of student life cycle data by demographic and non-demographic factors and improvements to provision such as academic skills and support for commuting students. Another promising indicator is BME student progression rates. After implementation of the ICF and targeted co-curricular activity (e.g. mentorship programmes) more BME students are now passing exams at first attempt, with a reduction in the proportion of BME students taking resits.

"The ICF's 'concept to review' has been key, and we have applied this to our recruitment strategy as well, so that inclusivity is meaningful from the very first point of contact students have with the course, through the full cycle of their journey with us." Course leader, Healthcare.

Winning hearts and minds are as important as action that leads to change in practice. Staff have notified us of over 40 projects inspired by the ICF, which demonstrates the scale of improvements in practice. Table 1 provides examples of these projects with reference to the ICF components as an illustration of changes that can be made. Case studies were selected to show the range and reach of the ICF at different levels and stages of the curriculum.

Table 1: The ICF in practice

\begin{tabular}{|l|l}
\hline Area & Key changes in practice
\end{tabular}


ICF principle 1 and 2, all strands.

The course was re-designed and changes include:

- Lectures on how mental health professionals might respond constructively to issues of diversity including cultural diversity, sexualities and religion. Black Christian students and Muslim students from Asian and Middle Eastern heritage backgrounds often say that this is the first time they've heard their religious commitments mentioned or taken seriously in their degrees.

- Sessions on Post-Colonial Social Psychology where students consider Western biases in studies of migration. Students bring in their own personal experience and family stories to construct a critical social narrative.

- Activities that enable Forensic Psychology students to consider biases and challenges faced by BAME and LGBT groups. The curriculum integrates issues relevant

Psychology to gender and social class including socio-economic status.

- Greater diversity in the images used online both in terms of BME people in professional roles or clinicians from a range of ethnicities. Staff have observed that after showing the video, students from these ethnic backgrounds are then more vocal in class discussions.

- Case studies and vignettes that include individuals from a variety of backgrounds. Care is taken to ensure that culture and ethnicity is woven into modules but without creating an impression that BAME people are more likely to experience mental health or forensic problems.

- Assessments that include an essay title option that might be of particular interest to BAME or other minority groups

Although not possible to directly attribute to the ICF, there has been a change in BME attainment gap for this course from $18 \%$ to $4 \%$ since the initiative has been introduced. ICF principles 1,2,3, all strands

The course team changed the title to include 'Social Pedagogy' to promote creativity and legitimise students'

Social Work and Social Care holistic contributions to this field of practice (professional endorsement received). Where required, changes were approved by the faculty quality committee.

The course was redesigned and changes include:

- Adding intersectionality and protected characteristic narratives and norms in relation to child development 


\begin{tabular}{|c|c|}
\hline & $\begin{array}{l}\text { - Replacing a second essay with a verbal group } \\
\text { presentation involving students making media choices, } \\
\text { with individual 500-word supporting statement } \\
\text { - Decolonising the reading list associated with this } \\
\text { teaching and learning, with the aim of decreasing } \\
\text { epistemic violence of, for example, women of colour and } \\
\text { those contributing knowledge from the global south } \\
\text { - Inviting students to create anything they like to benefit } \\
\text { children and young people (such as a comic strip, an app, } \\
\text { a sensory box etc) } \\
\text { - Involving representative practioners from diverse } \\
\text { backgrounds in roles that students will go into upon } \\
\text { graduation } \\
\text { - Offering a new assessment where students draw on their } \\
\text { own personal and/or professional experiences to write a } \\
\text { script that gives voice to their lived experiences, and } \\
\text { asking students to write an annotation for the script } \\
\text { which critiques and analyses systemic oppressions such } \\
\text { as institutional racism, sexism, homophobia and } \\
\text { disablism, }\end{array}$ \\
\hline Biosciences & $\begin{array}{l}\text { ICF principle 1, strand } 3 \text { and } 4 \text {. } \\
\text { Timetabling remains a major challenge e.g. 'my timetable } \\
\text { does not work for me' and this is especially pertinent as so } \\
\text { many of our BME students commute ( } 77 \% \text { ). What an } \\
\text { accessible timetable means can be perceived differently } \\
\text { between student groups and listening to. Therefore, the } \\
\text { emphasis has been on listening to student concerns and } \\
\text { providing in many cases what are relatively simple, common } \\
\text { sense and holistic resolutions. Significant issues were to deal } \\
\text { with bunching of teaching sessions on the same day ('being } \\
\text { too tired at the end of a long day', 'finding it hard to } \\
\text { concentrate') and single } 1 \text { hr sessions ('can seem pointless } \\
\text { coming in for such a short amount of time'). The timetable } \\
\text { was changed to: create and accessible curriculum in the } \\
\text { delivery and assessment. } \\
\text { Changes include: } \\
\text { - Developing a coherent policy for timetabling and } \\
\text { assessment scheduling } \\
\text { - Removal of single session timetabling and removal of } \\
\text { over-demanding timetable days } \\
\text { - Increasing empathy and understanding of staff of the } \\
\text { effect timetabling has on their students leading to } \\
\text { discussions on the pros and cons of late entry policies, } \\
\text { lecture capture and overly complex timetables }\end{array}$ \\
\hline
\end{tabular}




\begin{tabular}{|c|c|}
\hline & $\begin{array}{l}\text { - Review of assessment bunching towards the end of } \\
\text { modules and the creation of a school assessment calendar } \\
\text { has ensured that students have better opportunities to } \\
\text { prepare and do well in their exams } \\
\text { - An inclusive submission time (23.59) across the school } \\
\text { has standardised deadlines. } \\
\text { Impact: } 11 \text { out of } 15 \text { courses in the school have a value } \\
\text { added score of greater than } 1 \text {; the university subsequently } \\
\text { adopted this approach and new software to make } \\
\text { identification of lone sessions easier. }\end{array}$ \\
\hline Pharmacy & $\begin{array}{l}\text { ICF principle } 1 \text { and } 3 \text {, strands } 2 \text { and } 3 \\
\text { Students' profiles are diverse and due to their backgrounds, } \\
\text { some are not necessarily comfortable with communicating in } \\
\text { public settings, despite it being an important skill required } \\
\text { for practising pharmacists. Placement providers were keen } \\
\text { for students to strengthen these skills on course and given } \\
\text { the size of the groups in practicals/workshops an alternative } \\
\text { approach was needed to ensure all students could develop } \\
\text { these skills. } \\
\text { Changes made included: } \\
\text { - Three telephone lines were installed in the pharmacy } \\
\text { suite. } \\
\text { - Exercises were rewritten which created interaction } \\
\text { between prescriber and patient. Interaction with the } \\
\text { former requires the students to recall factual information } \\
\text { they had learnt previously, whereas interaction with the } \\
\text { latter requires them to understand simple questions from } \\
\text { the patient, apply what they have learnt and communicate } \\
\text { back in layman's language. } \\
\text { - Using class lists, tutors called asking to speak to a named } \\
\text { student at random and took notes so feedback could be } \\
\text { provided and coaching given where needed. The exercise } \\
\text { was repeated and students used the feedback received for } \\
\text { further calls. } \\
\text { Impact: Since implementing this initiative in } 2016 \text {, every } \\
\text { first year and foundation pharmacy student at Kingston has } \\
\text { been able to practise their communication skills and receive } \\
\text { personalised feedback in the manner described above. }\end{array}$ \\
\hline Chemistry & $\begin{array}{l}\text { ICF principle } 1,2 \text {, strand } 1-6 \\
\text { The framework and principles were used to review a first- } \\
\text { year unit on atmospheric chemistry and pollution. To enable } \\
\text { students to see themselves reflected in the curriculum a } \\
\text { project-based learning approach was adopted, requiring } \\
\text { teams to research and produce a report on a topic of their } \\
\text { choice. This allowed them the opportunity to co-create the }\end{array}$ \\
\hline
\end{tabular}


curriculum and focus on parts of the world of their choice. Lectures were replaced with support workshops and discussion and presentation sessions, where students could voice their own views on content of their choice and draw on their own cultural capital.

The framework highlighted that in making the curriculum more inclusive the delivery, assessment and feedback needed to be made more accessible. This prompted changes to the laboratory programme. Demonstration videos, computer animations and smart worksheets were developed to provide students with live support in and out of the class. These also provided immediate feedback, resubmission opportunities and their grade before the end of the class. This extra support allowed the start time to be moved from 9:00 am to 9:30 am to help commuter students. Traditional unseen examination questions on a range of potential topics was replaced with a longer seen examination question on their subject of their investigation and report.

To add to feedback from early module review and End of Module Evaluation questionnaires students were asked to reflect on their experiences of Project based learning and teamwork. A number of them indicated that they found it challenging and did not necessarily enjoy it but recognised its value as an employability skill.

\section{Discussion}

\section{Strengths and limitations}

The contribution of this paper is to strengthen arguments with practical examples of what works in an inclusive curriculum for improving equality of opportunity in HE. It is an important addition to the very few accounts of development and adoption of an inclusive curriculum internationally (Mountford-Zimdars, et al., 2015).

The ICF has proved credible at Kingston University because it is grounded in theory, is aligned to the institution's commitment to inclusivity, is embedded in quality assurance and enhancement activities and has practical utility that appeals to staff. The tools and the approach we have developed offer a steer while inspiring innovation for teaching small and large groups and supporting student success at all levels. The VA metric is a robust indicator of progress on inclusion and whilst cannot be directly linked to the ICF it is one of the major strategies used in the BME attainment gap 
achievement plan. The case studies reported to us by staff, demonstrate the impact and enthusiasm for the ICF in practice. However, for inclusive curricula to overcome challenges and create change there does need to be a commitment of institutional resources and senior leadership. Undoubtedly external pressure from the government, the National Union of Students and benchmarking exercises are important in providing the business imperative for institutions to take a close look at how their curriculum is benefiting all students and society.

Various methods of critical reflection supported learning through the implementation process, assessment of what was working and how to spread good practice. For example, firstly, staff feedback in ICF workshops was used to: refine the design and materials of the ICF training and the terms used in the framework; to build the accompanying resources; and to improve the communication of the ICF to staff. Secondly, a critical reflection exercise with the SiCCs resulted in the scaling down of the operation and the creation of a SiCC prompt sheet for consistency and confidence building.

\section{Impact on equality of opportunity}

The ICF at Kingston has brought together disparate narratives on inclusion and cohesively thread together what may seem like unrelated agendas. In this sense the ICF provides a framework to 'hang' different university schemes, projects and innovations together across all areas of the curriculum, to achieve cumulative transformation. The ICF has steered and inspired numerous changes to course design and delivery as well as co-curricular activity, for example, mentoring schemes offer different pathways for student groups where data demonstrates differentials in student outcomes. In recognition that outcomes are impacted by all aspects of the student journey, the ICF focuses not only on learning and teaching but on all aspects of the student experience. Consequently, there have been practice changes at the institutional level e.g. to timetabling protocols (to minimise lone teaching sessions for commuting students), to investment decisions about co-curricular activity (based upon analysis of reach and impact analysed by student group), to estates management (in terms of active learning spaces) etc.

We argue that staff development for academic and professional staff is needed to create a deeper understanding of the needs of our diverse student body, commitment to genuine student participation and the ability to create ideas for inclusion (Bendermacher, et al. 2019). The ICF is attempting to improve equality of opportunity through the whole student journey - from improving access to courses to support for where students go when they leave their course. This has methodological implications for what types of impact can be captured and attributed to the ICF. For example, development of 
measures for continuation of students who have technical qualifications $\left(\mathrm{BTECs}^{5}\right.$ ) compared to A levels (Banerjee et al., 2017).

\section{Next steps}

Further research is needed to explore and develop measures to assess quantitative and qualitative impact at module level and incorporate intersectionality (the influence of multiple factors on students) and additional exclusion factors, including students' sexual orientation and gender identity (NUS, 2014).

This is a preliminary paper that sets out the ICF within the context of Kingston University's work to reduce differentials and create an inclusive environment. We have built on this in follow up work and a national project funded by the Office for Students (OfS) Catalyst Programme. This focused on impact in different settings and specifically how the ICF and VA metric can be tailored and adapted in five other institutional contexts particularly to address the BME attainment gap. The findings have been reported by McDuff et al 2019 and is the subject of a follow up paper. It has allowed us to learn more about what works in different contexts and how institutions can variously use inclusivity and diversity as a powerful driver for change.

\section{Conclusion}

To improve equality of opportunity for all students HE institutions should develop more inclusive systems and curricula. There is increasing recognition that there needs to be a whole institution approach to creating inclusive curricula. The ICF is a tool which may be useful to HE providers as firstly, it guides institutions to become more accessible (spatially, practically, conceptually and culturally). Secondly it reflects the diversity of students (through co-construction approaches, appreciates that diversity has inherent education value) and prepares students to contribute positively to a global and diverse economy. Anyone in HE can use the ICF to inform improvements in inclusion at every level (teaching session, module, programme and institution) and for each strand of development (from concept to review).

Institutions which adopt the ICF can ensure successful implementation with leadership and support, staff engagement, staff skills and knowledge, student participation and measures of impact. Indicators of impact on equality of opportunities include measurable improvements in practice, BME attainment and fewer exam resits. Further research is needed to examine other types of impact and to inform spread of the ICF to other institutions.

\footnotetext{
${ }^{5}$ BTECs are vocational qualifications, rather than traditional academic courses. A key difference between BTECs and A-Levels is the way they are assessed. A-Levels mainly involve two years of study geared towards a few big tests at the end, whereas BTECs are continually assessed via coursework and practical projects.
} 


\section{References}

Absalom, M. and Vadura, K. (2006) Students perceptions of internationalisation of the curriculum, an Australian case study, Arts and Humanities in Higher Education, 5, 3, 317-334 DOI: $10.1177 / 1474022206067628$

Advance HE (2019) Equality and higher education: students statistical report. Available at:

https://www.advance-he.ac.uk/knowledge-hub/equality-higher-educationstatistical-report-2019 (Accessed 1 May 2020)Barnett, R. and Coate, K. (2005) Engaging the curriculum in higher education: Berkshire: SRHE and OUPress.

Blackmore, J. Thompson, P and Barty, K. (2006) Principal selection: homosocialbility, the search for security and the production of normalised principal identities, educational management, Administration and Leadership, 34, 297-317.

Bendermacher, G., oude Egbrink, M., Wolfhagen, H., Leppink, J. \& Dolmans, D. (2019) Reinforcing pillars for quality culture development: a path analytic model, Studies in Higher Education, 44:4, 643-662, DOI: 10.1080/03075079.2017.1393060

Berry, J and Loke, G. (2011) Improving the degree attainment of Black and minority ethnic students. York: ECU/HEA.

Bhopal, K. (2017) Addressing racial inequalities in higher education: equity, inclusion and social justice, Ethnic and Racial Studies, 40:13, 22932299, DOI: $10.1080 / 01419870.2017 .1344267$

Business, Innovation and Skills (2013) The benefits of higher education participation for individuals and society. Research paper no. 146. https://assets.publishing.service.gov.uk/government/uploads/system/u ploads/attachment data/file/254101/bis-13-1268-benefits-of-highereducation-participation-the-quadrants.pdf

Bovill, C. (2010) Students and staff co-creating the curriculum: research into three case studies from Scotland, Ireland and the USA, York: HES https://www.heacademy.ac.uk/system/files/university_of_glasgow_co -creating_the_curriculum.pdf

Bowl, M. (2005) Valuing diversity in the social sciences curriculum. Learning and teaching in the social sciences. 2 (2), pp.121-136.

Brinks, C. (2009) 'Standards will drop': dispelling fears about the equality agenda in higher education [Online]. Available at 
http://www.ecu.ac.uk/wpcontent/uploads/2009/01/E for_E The futur e of equality in he.pdf

Britton, J., Dearden, 1., Shephard, N. and Vignoles, A. (2016) IFS Working Paper (W16/06) How English domiciled graduate earnings vary with gender, institution attended, subject and socio-economic background. Institute of Fiscal Studies.

Broeke, S. and Nicholls, T. (2007) Ethnicity and degree attainment, Research Report RW92 London: Department for Education and Skills. http://webarchive.nationalarchives.gov.uk/20130401151715/http://ww w.education.gov.uk/publications/eOrderingDownload/RW92.pdf

Carey, P. (2012) Exploring variation in nurse educators' perceptions of the inclusive curriculum, International Journal of Inclusive Education, 16, 7: 741-755 http:dx.doi.org/10.1080/13603116.2010.516773

Collins, A., Azmat, F. and Rentschler, R. (2018) 'Bringing everyone on the same journey': revisiting inclusion in higher education, Studies in Higher Education, DOI: 10.1080/03075079.2018.1450852.

Cameron, H. (2019) Bookishness, blue skies, bright hats and brickies: discourse and positioning in academics' conversations around 'academic intelligence' and the 'good' student, Studies in Higher Education, 44:2, 318-332, DOI: 10.1080/03075079.2017.1364718

Daddow, A., Moraitis, P. and Carr, A. (2013) Non-traditional students in tertiary education: inter-disciplinary collaboration in curriculum and pedagogy in community services education in Australia, International Journal of Inclusive Education, Vol. 17, No. 5, 480-489, http://dx.doi.org/10.1080/13603116.2012.685765

DeRouise, J. (2014) Exploring the diffusion of innovation in higher education. PhD dissertation. Pennsylvania State University, USA. https://etda.libraries.psu.edu/files/final submissions/10437

Disabled Students' Sector Leadership Group (2017) Inclusive teaching and learning in higher education as a route to excellence, Available at:

https://assets.publishing.service.gov.uk/government/uploads/system/uploads /attachment_data/file/587221/Inclusive_Teaching_and_Learning_in Higher_Education_as_a_route to-excellence.pdf

Douglas, D. and Halas, J. (2013) The wages of whiteness: confronting the nature of ivory tower racism and the implications for physical education, Sport, Education and Society 18, 4: 453:474 http://dx.doi.org/10.1080/13573322.2011.602395

DSA-QG, (2016) Disabled Student Allowance Guidance for New Students. Available at: http://www.dsa-qag.org.uk/docman-public/assessors- 
$\underline{\text { tab/1851-dsa-guidance-for-new-dsa-students-in-ay-2016-17-final- }}$ 15 th-feb/file

Dunne, L. (2016) Investigating the benefits of student engagement for 'Hard-to-Reach' Students, Teaching Excellence Framework: raising quality standards conference, $14^{\text {th }}$ July 2016.

Equality Challenge Unit (2018) Equality in higher education: students statistical report 2018, Available at: https://www.ecu.ac.uk/publications/equality-higher-educationstatistical-report-2018 (Accessed 4 April 2019)

European Commission (2019) Inclusive and connected higher education. https://ec.europa.eu/education/policies/higher-education/inclusiveand-connected-higher-education en

Felder, R. and Brent, R. (2005) Understanding student difference, Journal of Engineering Education, 94,1 57-72.

French, A. (2013) 'Let the Right Ones In!': widening participation, academic writing and the standards debate in higher education, Power and Education, 5, : 236-247.

Garvey, M. (2011) Inclusion and the student voice: lessons from the Trinity inclusive curriculum strategy, Thomas, L. and Tight, M. (eds.) Institutional Transformation to Engage a Diverse Student Body, Bingley: Emerald.

Haigh, M. (2009) Fostering cross-cultural empathy with non-western curricular structures, Journal of Studies I, International Education, 13, 2 271-284 DOI:10.1177/1028315308329791

Haigh, M. (2002) Internationalisation of the curriculum: designing inclusive education for a small world, Journal of Geography in Higher Education, 26, 1:49-66.

Hammond, J., Marshall-Lucette, S., Davies, N., Ross, F., Harris, R. (2017) Spotlight on equality of employment opportunities: A qualitative study of job seeking experiences of graduating nurses and physiotherapists from black and minority ethnic backgrounds. International Journal of Nursing Studieshttp://dx.doi.org/10.1016/j.ijnurstu.2017.07.019 Harding, S. (1986) The science in question, Milton Keynes: Open University Press.

HEA (2014) Higher Education Academy. Undergraduate retention and attainment across the disciplines. Available at: https://www.heacademy.ac.uk/resource/undergraduate-retention-andattainment-across-disciplines 
HEFCE (2015) Differences in degree outcomes: The effect of subject and student characteristics.

http://www.hefce.ac.uk/media/HEFCE,2014/Content/Pubs/2015/2015 21/HEFCE2015 21.pdf

HESA (2017/2018) UK statistics. Available at https://www.hesa.ac.uk/dataand-analysis/

Henrion, C. (1997) Women in mathematics: the addition of difference, Bloomington: Indiana University Press.

Hill, P. (2000) Black Feminist Thought: Knowledge, Consciousness, and the Politics of Empowerment. New York: Routledge.

Hooks, b. (1004) Teaching to transgress: Education as the practice of freedom, London: Routledge.

Hockings, C., Cooke, S., Yamashita, H., McGinty, S. and Bowl, M. (2009b) 'I'm neither entertaining nor charismatic...' Negotiating university teacher identity within diverse student groups. Teaching in Higher Education. 14 (5), pp.483-494.

Hughes, A. (2016) Exploring normative whiteness: ensuring inclusive pedagogic practice in undergraduate fieldwork teaching and learning. Journal of Geography in Higher Education, 40(3), pp. 460-477. ISSN (print) 0309-8265. DOI: 10.1080/03098265.2016.1155206.

https://www.tandfonline.com/doi/abs/10.1080/03098265.2016.1155206?jou $\underline{\text { rnalCode }=\operatorname{cjgh} 20}$

Hughes, A., Mohamad, K., McDuff, N. and Michener, C. (2019) Curriculum co-creation as a transformative strategy to address differential student outcomes: the example of Kingston University's Student Curriculum Consultant Programme, Compass.

Hughes, A. and McDuff, N. (2020) Inclusive teaching and learning practices in Geography in Walkington, H. Hill, J. and Dyer, S. (eds.) The Handbook of Teaching and Learning in Geography, London: Edward Elgar Publishing Ltd.

IFS (2016) How English domiciled graduate earnings vary with gender, institution attended, subject and socio-economic background. https://www.ifs.org.uk/publications/8233

Karanxha, Z., Agosto, V. and Bellara, A. (2014) The Hidden Curriculum: candidate diversity in educational leadership preparation, Journal of Research on Leadership Education, 9, $1334-58$ DOI:10.1177/1942775113498374

Kelly, E. (1985) Reflections on gender and science, New Haven: Yale University Press. 
Karimi, F. and Matous, P. (2018) Mapping diversity and inclusion in student societies: A social network perspective. Computers in Human Behaviour, 88: 184-194.

Krause, K. and Armitage, L. (2014) Australian student engagement, belonging, retention and success: a synthesis of the literature, York: HEA. Available at:

https://www.heacademy.ac.uk/sites/default/files/resources/australian_studen t engagement lit_syn 2.pdf

Lee, A. Poch, R., Shaw, M. and Williams, R. (2014) Engaging diversity in undergraduate classrooms: ASHE Higher Education Report Vol. 38, No. 2.

Lazenby, H. (2016) What is equality of opportunity in education? Theory and Research in Education. 14:1, 65-76. DOI:

$10.1177 / 1477878515619788$

Madriaga, M. (2018) Antiblackness in English higher education, International Journal of Inclusive Education, DOI: 10.1080/13603116.2018.1512660.

Maila, M. (2010) Curriculum as open-ended inquiry in higher education, Africa Education Review, 7,2 263-282 DOI: $10.1080 / 18146627.2010 .515385$

Manley, S. and De Graft-Johnson, A. (2013) Towards inclusion: rethinking architectural education, Construction Management and Economics, 31, 8, 914-927, http://dx.doi.org/10.1080/01446193.2013.797093

Marginson, S. (2019) three ways a higher education system can push towards more equal opportunity. Higher Education Policy Institute. Available at https://www.hepi.ac.uk/2019/02/11/three-ways-a-highereducation-system-can-push-towards-more-equal-opportunity/

Marquis, E., Jung, B., Schormans, A., Lukmanji, S., Wilson, R and Baptiste, S. (2016) Developing inclusive educators: enhancing the accessibility of teaching and learning in higher education, International Journal for Academic Development, http://dx.doi.org/10.1080/1360144X.2016.1181071

May, H. and Bridger, K. (2010) Developing and embedding inclusive policy and practice in higher Education, York: Higher Education Academy, Available at https://www.heacademy.ac.uk/sites/default/files/developingembeddin ginclusivepp_report.pdf

May, H. and Felsinger, A. (2010) Strategic approaches to disabled student engagement, York: Higher Education Academy, Available at 
http://www.heacademy.ac.uk/resources/detail/inclusion/Disability/Stra tegicApproachesFinalReport.

May, H. and Thomas, L. (2010) Embedding equality and diversity in the curriculum: Self Evaluation Framework. The Higher Education Academy. Available at https://www.sparqs.ac.uk/upfiles/HEA\%20Equality\%20and\%20Diver sity\%20Framework.pdf

McCarthy-Brown, N. (2014) Decolonizing dance curriculum in higher education: one credit at a time, Journal of Dance Education, 14, 125129DOI: $10.1080 / 15290824.2014 .887204$

McCulloch, A. (2009) The student as co-producer. Studies in Higher Education, 34, 2, 171-183.

McDuff, N., Tatam, J., Beacock, O. and Ross, F. (2018) Closing the attainment gap for students from black and minority ethnic backgrounds through institutional change. Widening Participation and Lifelong Learning, 20(1), pp. 79-101. ISSN (print) 1466-6529. https://doi.org/10.5456/WPLL.20.1.79

McDuff, Nona; Hughes, Annie., Sharma, Sonya. (2019) Chapter 9: Inclusive curricula. In: Marshall, S. (ed) A Handbook for Teaching and Learning in Higher Education. Fifth edition. Routledge, pp1-376. ISBN 9780367200817.

McDuff, Nona, Tatam, J., Fegan, E., Beacock, O., Hughes, A. (2019) Use of a Value-Added Metric and an Inclusive Curriculum Framework to address the Black and Minority Ethnic Attainment Gap. Research Report produced in partnership between Kingston University, De Montfort University, University College London, University of Greenwich, University of Hertfordshire and the University of Wolverhampton. Office of Students.

McKay, J. \& Devlin, M. (2014) 'Uni has a different language ... to the real world': demystifying academic culture and discourse for students from low socioeconomic backgrounds, Higher Education Research \& Development, 33:5, 949-961, DOI:10.1080/07294360.2014.890570. http://dx.doi.org/10.1080/07294360.2014.890570

McKinsey (2018) Delivering through diversity, McKinsey. Available at https://www.mckinsey.com/business-functions/organization/ourinsights/delivering-through-diversity

Mbembe, A. J. (2016) Decolonizing the university: new directions, Arts and Humanities in Higher Education, 15, 1 29:45.

Meuleman, A., Garrett, R., Wrench, A. and King, S., (2015) 'Some people might say I'm thriving but...': non-traditional students experiences of 
university, International Journal of Inclusive Education, http://dx.doi.org/10.1080/13603116.2014.945973

Mountford-Zimdars, A., Sabi, D., Moore, J., Sanders, J., Jones, S., Higham, L. (2015) Causes of differences in student outcomes. A report to HEFCE by King's College London, ARC Network and The University of Manchester, Higher Education Funding Council for England. Available at https://dera.ioe.ac.uk/23653/1/HEFCE2015 diffout.pdf

Nunan. T., George, R. and McGausland, H. et. al. (2000) Inclusive education in universities: why it is important and how it might be achieved, International Journal of Inclusive Education, 4,1:63-88.

National Union of Students (2014) Education Beyond the Straight and Narrow: LGBT students' experience in higher education. Available at: http://www.nus.org.uk/global/lgbt-research.pdf

Northedge, A. (2003) Rethinking teaching in the context of diversity, Teaching in Higher Education, 8:1, 17-32, DOI: 10.1080/1356251032000052302. Available at: http://dx.doi.org/10.1080/1356251032000052302

Office for Students (2018) Equality and diversity objectives 2018/19. Available at https://www.officeforstudents.org.uk/about/equality-anddiversity/objectives/

Office for Students (2019) Access and participation plans. Available at https://www.officeforstudents.org.uk/advice-and-guidance/promotingequal-opportunities/access-and-participation-plans/

Parker, H., Hughes, A., Marsh, C., Ahmed, Sadia, Cannon, J., TaylorSteeds, E., Jones, L. and Page, N. (2017) Understanding the different challenges facing students in transitioning to university particularly with a focus on ethnicity. New Directions in the Teaching of Physical Sciences, 12, ISSN (online) 2051-3615. https://journals.le.ac.uk/ojs1/index.php/newdirections/article/view/2450

Reay, D., Ball, S. and David, M. (2002) It's taking me a long time but I'll get there in the end': Mature students on access courses and higher education choice, British Education Research Journal, Volume 28:1, February 2002, 5-19.

Reay, D. Crozier, G. and Clayton, J. (2010) Fitting in' or 'standing out': Working-class students in UK higher education, British Educational Research Journal, Vol.36(1), pp.107-124

Richardson, J. (2015) The under-attainment of ethnic minority students in UK higher Education: what we know and what we don't know, 
Journal of Further and Higher Education, 39, 2: 278:291 http://dx.doi.org/10.1080/0309877X.2013.858680

Richardson, J. (2012) The attainment of White and ethnic minority students in distance education, Assessment and Evaluation In Higher Education, 37,4: 393: 408.

Richardson, J. (2008) The attainment of ethnic minority students in UK higher education, Studies in Higher Education, 33, 1: 33-8.

Robbins, C. (1963) Higher Education. Report of the Committee appointed by the Prime Minister under the Chairmanship of Lord Robbins. London: HMSO.

Rogers, E. (1962). Diffusion of Innovations. Free Press of Glencoe, Macmillan Company.

Ross, F., Tatam, J., Livingstone, A., Beacock, O. and McDuff, N. (2018) The great unspoken shame of UK Higher Education: addressing inequalities of attainment. African Journal of Business Ethics, 12(1), ISSN (print) 1817-7417. https://eprints.kingston.ac.uk/40707/

Runneymede (2015) Aiming Higher: Race, Inequality and Diversity in the Academy. ISBN: 978-1-909546-06-0 Available at: http://www.runnymedetrust.org/uploads/Aiming\%20Higher.pdf

Rois, D., Stewart, A. and Winter, D. (2010) "Thinking she could be the next president": why identifying with the curriculum matters, Psychology of Women Quarterly 34, 328-338.

Savas, G. (2014) Understanding critical race theory as a framework in higher educational research, British Journal of Sociology of Education, 35:4, 506-522, DOI: 10.1080/01425692.2013.777211

Savvidou, C. (2011) Exploring teachers' narratives of inclusive practice in higher education, Teacher Development, 15, 1 53-67 DOI: $10.1080 / 13664530.2011 .555224$

Seale, J., Draffan, E. and Wald, M. (2010) Digital agility and digital decision-making: conceptualising digital inclusion in the context of disabled learners in higher education, Studies in Higher Education, 35:4, 445-461, DOI: 10.1080/03075070903131628

Shiner, M. and Modood, T. (2002) Help or Hindrance? Higher Education and the Route to Ethnic Equality, British Journal of Sociology of Education, 23:2, 209-232, DOI: 10.1080/01425690220137729

Singh, G. (2011) Black and minority ethnic (BME) students participation in higher education: improving retention and success. A synthesis of research evidence York: Higher Education Academy. 
Spanier, B. (1995) Impartial Science: Gender Ideology in Molecular Biology, Indiana University Press, Bloomington.

Song-Turner, H. and Willis, M. (2011) Re-engineering the course design and delivery of Australian tertiary education programmes: perspectives from Chinese students, Journal of Higher Education Policy and Management, 33, 5: 537-552 DOI: 10.1080/1360080X.2011.605228

Soria, K. and Bultmann, M. (2014) Supporting working-class students in higher education, NACADA Journal, 2014, 34(2), p.51-62.

Stevenson. J. (2012) Black and minority ethnic student degree retention and attainment. HEA. Available at https://www.heacademy.ac.uk/system/files/bme_summit_final_report. pdf

Svensson, L. and Wihlborg, M. (2010) Internationalising the content of higher education: the need for a curriculum perspective. Higher Education, 60: 595-613 DOI: 10.1007/s10734-010-9318-6

Swanger, D. (2016) Innovation in higher education. Can colleges really change? Available at https://www.fmcc.edu/about/files/2016/06/Innovation-in-HigherEducation.pdf

Tange, H. and Kastberg, P. (2013) Coming to terms with 'double knowing': an inclusive approach to international education, International Journal of Inclusive Education, 17, 1 1-14 DOI:10.1080/13603116.2011.580460.

Tead, O. (1956) The problem of equality in higher education, The Journal of Higher Education, 27:1, 1-55, DOI: 10.1080/00221546.1956.11779470

Thomas, C. (2014) No Longer Visible, in Thomas, C. (2014, ed.) Inclusive teaching: presence in the classroom, New Directions for Teaching and Learning, No. 140. San Fransisco: Jossey-Bass pp. 1-10.

Thomas, L. and Tight, M. (2011) Institutional transformation to engage a diverse student body: International Perspectives on Higher Education Research v. 6, United Kingdom: Emerald Group Publishing Ltd.

Thomas, L. and May, H. (2010) Inclusive learning and teaching in higher education, HEA. Available at https://www.heacademy.ac.uk/sites/default/files/inclusivelearningandt eaching finalreport.pdf

Toni, N. (2011) Dismantling racial and hegemonic boundaries for an inclusive higher education, Africa Insight, 40, 4 187-197. 
Thornton, M., Bricheno, P., Iyer, P., Reid, I., Wankhede, G. and Green, R. (2010) Diversity and social integration on higher education campuses in India and the UK: student and staff perspectives, Research in PostCompulsory Education, 15:2, 159-176, DOI: 10.1080/13596741003790682.

Umbach, P. (2006) The contribution of faculty of color to undergraduate education. Research in Higher Education, 47(3), pp.317-345.

UUK (2016) Working In Partnership: Enabling Social Mobility In Higher Education, the final report of the Social Mobility Advisory Group. Available at:

http://www.universitiesuk.ac.uk/policy-andanalysis/reports/Documents/2016/working-in-partnership-final.pdf

U.S. Department of Education (2016) Advancing Diversity and Inclusion in Higher Education. Office of Planning, Evaluation and Policy Development and Office of the Under Secretary, Washington, USA.

Westen, P. (1985) The concept of equality of opportunity. Ethics 95: 837850.

Winter, L. (2018) Relational equality in education: what, how, and why?, Oxford Review of Education, 44:3, 338-352, DOI:

10.1080/03054985.2017.1391761

Wray, M. (2013) Developing an inclusive culture in higher education: final report. York: Higher Education Academy.

Zepke, N. and Leach, L. (2007) Improving student outcomes in higher education: New Zealand teachers' views on teaching students from diverse backgrounds. Teaching in Higher Education. 12 (5-6), pp.655-668

Acknowledgments

The authors would like to thank colleagues at Kingston University for implementing innovative inclusive curriculum changes, which are showcased in this paper. We are also grateful to the anonymous reviewers for their encouraging and helpful comments. 